\title{
Self-Efficacy and College Readiness of Senior High School Students of a Catholic High School
}

\author{
Herbert T. Martinez ${ }^{1}$ and Ma. Wilma M. Maravilla ${ }^{2}$ \\ St. Vincent's High School of San Remegio, Inc., Antique, Philippines \\ 2University of Negros Occidental-Recoletos, Bacolod City, Philippines
}

\begin{tabular}{l} 
Article history \\
Submitted: 25 October 2020 \\
Revised: 11 November 2020 \\
Accepted: 12 November 2020 \\
\hline Keywords \\
Guidance and Counseling \\
Self-Efficacy \\
College Readiness \\
Senior High School Students \\
Catholic School \\
Descriptive-Correlational \\
Antique
\end{tabular}

\section{Article history}

Revised: 11 November 2020

Keywords

Guidance and Counseling

Self-Efficacy

College Readines

Catholic School

Antique
Introduction. Efficacy beliefs are the foundation of human agency. Beliefs influenced students' motivation to learn. Students' self-efficacy beliefs could be improved as long as one has a clear idea about the sources of self-efficacy beliefs. Students enable them to grow as selfefficient individuals and overcome problems they face in educational stages or their future life if provided with the opportunity and training on self-efficacy beliefs. Hence, this paper describes the level of efficacy and degree of college readiness of senior high students of a Diocesan Catholic School in Antique during the School Year 2019-2020. Likewise, it explores the significant difference between students' demographics, self-efficacy, and college readiness. Moreover, it determines the correlation between self-efficacy and college readiness of the students; and whether self-efficacy influenced college readiness.

Methods. A descriptive, comparative, and correlational research design was employed to assess, compare, and correlate self-efficacy and college readiness of senior high school students of a Diocesan Catholic School in Antique during the School Year 2019-2020. Using stratified random sampling, 154 students participated in the study. The data was gathered using a standardized instrument by Zimmerman, Kitsantas, and Campillo (2005) and a modified instrument used by Gealon and Magallanes (2019). Mean, Standard Deviation, and Spearman rank correlation were used to analyze the data.

Results. The findings of the study revealed that the level of self-efficacy of senior high school students is generally high regardless of sex, family monthly income, family structure, and parenting style. Likewise, the degree of college readiness of senior high school students is very high regardless of sex, family monthly income, family structure, and parenting style. As to the difference between demographics and self-efficacy, the findings reveal that there is no significant difference. On the other hand, there is no significant difference between the demographics and college readiness of senior high school students. In addition, the findings indicated that self-efficacy significantly influenced college readiness. Finally, a significant relationship was found between self-efficacy and college readiness of senior high school students.

Conclusion. Senior high school students of a Catholic high school in the province of Antique generally are college-ready. Their high level of self-efficacy for learning speaks clearly of the efficaciousness in studying, reading, writing, note-taking, and test preparation they obtain. This also connotes that students with high self-efficacy have exerted much effort and persevered long to accomplish the tasks than students with low self-efficacy. Likewise, the very high degree of college readiness speaks of the commendable knowledge, skills and strategies, learning experiences, and learning outcomes they obtain in their senior high school years. This implies that they are ready to expose themselves to various learning processes requisite to college preparation and college life. The role of parents, teachers, and other non-parental figures in the development of student's self-efficacy and college readiness cannot be underrated. They still play a significant role in boosting self-efficacy and enhancing college readiness. With the results generated from this study, the researcher found out that a college readiness program should be developed and integrated into its guidance program. This will help students increase their beliefs in their capabilities and design activities that will develop their skills, knowledge, and behaviors expected upon finishing senior high school and entering college. 
Practical Value of the Paper. The study significantly contributes to the few existing literature on self-efficacy and college readiness in Catholic schools. In addition, the findings of the study provided information to school administrators, guidance counselors and associates, and teachers in formulating a college readiness program that will address students' needs and concerns.

\section{References}

Alfaiz, M. (2016). Perceived Self-efficacy as a Predictive of Student Readiness and Creativity in College Tasks. ASEAN Comparative Education Research Network Conference.

Alt, D. (2015). First-source female college students' academic motivation as a function of perceived parenting styles: A contextual perspective. Journal of Adult Development, 22, 63-75.

Arslan, A. (2012). Predictive Power of the Sources of Primary School Student's Self-Efficacy Beliefs on their Self Efficacy Belief for learning and Performance. Educational Sciences Theory \& Practice, 12(3) 1915-1920.

Barnes, W., \& Slate, J.R. (2013). College Readiness Is Not One-Size-fits-all. Current Issues in Education, 16(1). http:// cie.asu.edu/ojs/index.php/cieatasu/article/view/1070.

Cuy, N.A. \& Salinas, E.M. (2019). Aspiration and Readiness of Filipino Senior High School Students in Pursuing a College Degree. Open Journal of Social Sciences, 7, 143-152. https://doi.org/10.4236/jss.2019.75012.

Dagdag, J.D., Cuizon, H.G., \& Bete, A.O. (2019). College Student Problems and their Link to Academic Performance: Basis for Needs-driven Student Programs. Journal of Research, Policy, and Practice of Teachers and Teacher Education. 9(2), $54-56$.

Dullas, A. R. (2018). The Development of Academic Self-Efficacy Scale for Filipino Junior High School Students. Frontiers in Education. 3(19). doi:10.3389/feduc.2018.00019.

Gealon, R., \& Magallanes, C. (2019). Career Preference and College Readiness of Senior High School Students. A Thesis Presented to the Faculty of Recoletos de Bacolod Graduate School. University of Negros OccidentalRecoletos, Bacolod City, Philippines.

Keshavarz, S., Mounts, N.S. (2017) Perceived Parenting Style of Fathers and Iranian Adolescents' Self-efficacy: The Moderating Role of Gender and Education, The Journal of Genetic Psychology, 178:5, 281-290, DOI: 10.1080/00221325.2017.1355772.

Villas, J. P. (2019). Self-efficacy of Filipino Senior High Students: Differences Among Tracks/Strand and Type of School. Journal of Education and Practice, 10(8). DOI: 10.7176/JEP.

\section{Correspondence:}

Herbert T. Martinez [junherbert22@gmail.com]

https://orcid.org/0000-0002-3617-397X 